\title{
Ethnozoological study of animals based medicine used by traditional healers and indigenous inhabitants in the adjoining areas of Gibbon Wildlife Sanctuary, Assam, India
}

Manash Pratim Borah and Surya Bali Prasad ${ }^{*}$

\begin{abstract}
Background: India has an immense faunal, floral, as well as cultural diversity with many ethnic communities who are primarily dependent on the traditional medicinal system for their primary health care. Documentation and evaluation of this indigenous remedial knowledge may be helpful to establish new drugs for human health. The present study is intended to look into different zootherapeutic medicinal uses in the traditional health care system among the native inhabitants adjacent to the Gibbon Wildlife Sanctuary, Assam, India.

Methods: Field survey was carried out from March 2015 to August 2015 by personal interviews through semistructured questionnaires. In some cases where participants were uncomfortable with the questionnaires, informal interviews and open group discussions were conducted with a total of 62 indigenous respondents (43 male and 19 female) who provided the information regarding various medicinal uses of animals and their products (local name of animal, mode of preparation, application etc).

Results: The study recorded a total of 44 different species, 44 genera and 36 families of animals which are used for the treatment of 40 different ailments. Insects occupied the highest uses (30.9\%), followed by mammals (23.8\%), fishes (16.7\%), reptiles (11.9\%), amphibians (7.1\%), annelids (4.8\%) and gastropods (4.8\%). Further, some zootherapeutic animals i.e. cockroach (Periplaneta americana), praying mantis (Mantis religiosa) and earthworms (Metaphire houletti, Pheretima posthum) are used for the treatment of asthma, otorrhoea and cancer respectively.

Conclusion: The findings suggest that the traditional zootherapeutic remedial measures followed by the native people adjacent to Gibbon Wildlife Sanctuary plays an important role in their primary health care. The documentation of this indigenous knowledge on animal based medicines should be very helpful in the formulation of strategies for sustainable management and conservation of bio-resources as well as providing potential for the novel drugs discovery.
\end{abstract}

Keywords: Ethnozoology, Zootherapy, Traditional healers, Fidelity level

* Correspondence: sbpnehu@hotmail.com

Cell and Tumor Biology Laboratory, Department of Zoology, School of Life

Sciences, North-Eastern Hill University, Umshing, Shillong 793022, India 


\section{Background}

Bioresources involving both plants and animals have been used in the indigenous healing practices by different cultures since ancient time [1, 2]. In modern society also traditional medicinal knowledge constitutes an important alternative in health care system. About $70-80 \%$ of the world rural population depends on traditional medicine for its primary health care [3]. The percentage of the population using traditional medicines for primary health care is more (60-90\%) in developing countries than that in developed countries (23-80\%) [4]. Around $60 \%$ of commercially available drugs are based on bioactive compounds extracted from natural resources traditionally used by various indigenous cultures around the globe [5]. Although plants and plant derivatives have been used as a major constituent of traditional medicine, the identification of animal resources for medicinal cure is also important in human health care $[1,6]$.

Zootherapy is defined as healing of human ailments by using medicines prepared from different animals and/or animal derived byproducts [7]. Zootherapy constitutes a significant substitute among many other known therapies practiced worldwide [1]. In Latin America, 584 animals distributed in 13 taxonomic categories were recorded with traditional therapeutic medicinal value [8], while 283 animal species were reported to be used for the treatment of various ailments in Brazil [9]. In Bahia, the Northeast State of Brazil, over 180 animal species were recorded for the treatment in traditional health care practices [10]. The rural community in the semi-arid region of Northeastern Brazil were reported to use 51 animal species to treat different ailments [11]. Toba (qom) communities of Argentine Gran Chaco region have been documented to use 72 animal species belonging to 52 families as a part of animal pharmacopeia [12]. In Traditional Chinese medicine, more than 1500 animal species have been reported to be of some medicinal importance [13]. A review on the global traditional use of primates reported the use of 110 species of primates belonging to 41 genera and 11 families in traditional folk medicine and in magic-religious rituals [14]. Lev and Amar (2000) documented the use of 20 animal species as traditional drugs in Israel [15]. Alves and Rosa (2007) recorded 138 animal species being used in traditional medicine to treat 100 illnesses by the fishing communities of the North and Northeastern regions of Brazil [16]. An overview of the global traditional uses of reptiles revealed that at least 165 reptile species belonging to 104 genera and 30 families are used in traditional folk medicine around the world [17].

India has a great faunal diversity accounting about $10 \%$ of the reported biological species on the planet and ranks first place in terms of insects $(54,600)$, followed by fishes (2546), aves (1232), reptiles (456), mammals (390) and amphibians (209) [18, 19]. Various zootherapeutic traditional medicines have been reported and documented in great historical books like Ayurveda and Charak Samhita in India. About 15-20\% of the Ayurvedic medicines are based on animal derived substances [20]. Different tribes and ethnic communities inhabiting in different parts of India have a rich knowledge about animals and their medicinal value for their primary health care needs [21]. Therefore, it is utmost important to record the conventional indigenous knowledge of different ethnic communities as many rural communities are loosing their socioeconomic and cultural characteristics [22].

North-eastern region of India is inhabited by various ethnic groups and tribes with wide cultural diversity [23]. As per 2011 census, the North-eastern region is inhabited by a total of 427 tribal groups which have their own traditional cultural identity. There are only a few reports available from the region about the use of animals in traditional medicine. The traditional methods of treating various ailments using 81 species of edible and therapeutic insects and 36 vertebrate species by the Nyishi and Galo tribes of Arunachal Pradesh were reported [24, 25]. Twenty-six animal species were reported for the treatment of different diseases like asthma, tuberculosis, rheumatic pain, paralysis, etc. by different Naga tribes of Nagaland [26]. Recently, indigenous Khasi tribes of East Khasi hills district, Meghalaya were reported to use 13 animals against asthma, anemia, diarrhea, cough, fever etc. in their traditional zootherapeutic practices [27].

Among the eight Northeastern States of India, Assam is the second largest State having rich, unique ethnic and cultural diversity, richness in forest resources and wildlife sanctuaries. Many reports on the plant based traditional medicine used by the people of Assam have been documented [28]. However, only a few reports are available on the study of zootherapeutic remedial uses. Thirty-four different animal species have been recorded for the treatment of 34 different ailments among Biate tribes in the Dima Hasao district of Assam [29]. A total of 26 ethnomedicinal animals and animal products were accounted for the treatment of different diseases like jaundice, asthma, pneumonia, etc. among the indigenous inhabitants in adjoining areas of Pobitora Wildlife Sanctuary, Assam, India [30]. Among Karbi community, a total of 48 different animals were reported to be used for different therapeutic purposes against various diseases like piles, cancer, tuberculosis, eczema etc. [31].

The knowledge on the use of different animals in traditional medicine by different ethnic communities is generally passed orally from one generation to another generation and this knowledge is sometimes lost with the death of the elderly knowledgeable person. Nowadays, 
Indian traditional knowledge system is fast eroding due to urbanization. So, it is vital to study and document the ethnobiological information regarding the therapeutic use of different animals in traditional medicine among different ethnic communities before the traditional cultures are completely lost [32].

Many studies have been undertaken on Gibbon Wildlife Sanctuary related with the Hollock Gibbon conservation, faunal diversity and medicinal plants [33-35], however, there is no report available about its ethnozoological value utilized by the people inhabiting adjacent to this Sanctuary. Thus, the present study involving the documentation of traditional zootherapeutic medicinal remedies used by indigenous people inhabiting in the adjoining areas of Gibbon Wildlife Sanctuary was undertaken which may provide information in making strategies for sustainable utilization of natural resources and biodiversity and also protect traditional knowledge for future generation.

\section{Methods}

Study area

Gibbon Wildlife Sanctuary is the only sanctuary named after non-human primate the Hoolock Gibbon (Hylobates hoolock). It is located in the close proximity of the Naga Hills in the Jorhat district of Assam, India and covers an area of about $20.98 \mathrm{sq}$. km. extended between latitude $26^{\circ} 40^{\prime} \mathrm{N}$ to $26^{\circ} 45^{\prime} \mathrm{N}$ and $94^{\circ} 20^{\prime} \mathrm{E}$ to $94^{\circ} 25^{\prime} \mathrm{E}$ longitude (Fig. 1). The sanctuary is topographically characterized by an almost level land with an average contour height of $90 \mathrm{~m}$ from mean sea level with an average annual rainfall of $249 \mathrm{~cm}$ [36]. The sanctuary is famous for harbouring seven species of primates namely Western Hoolock Gibbon (Hoolock hoolock), Stump-tailed

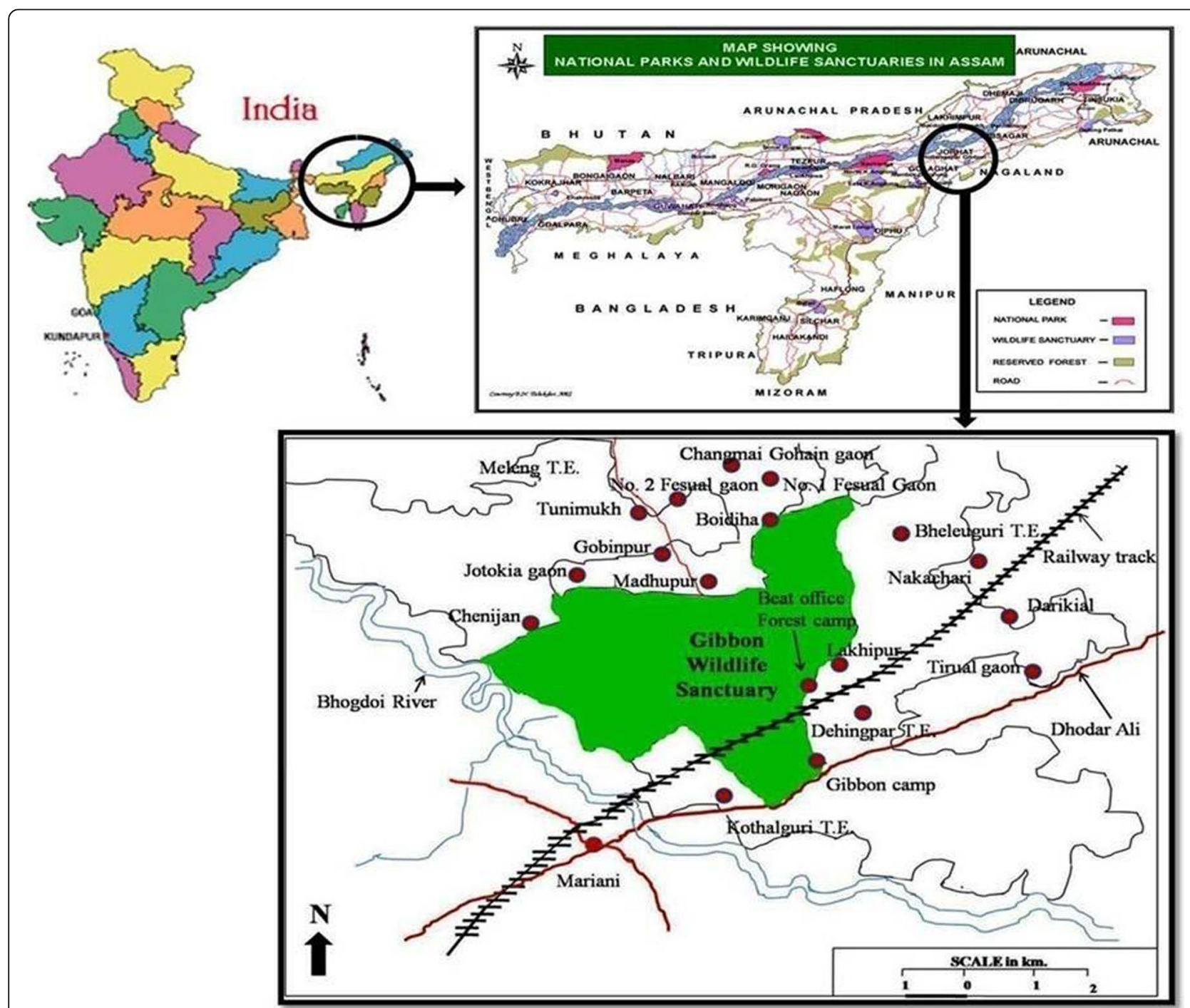

Fig. 1 Map showing the sites of field survey

marks) 
Macaque (Macaca arctoides), Eastern Assamese macaque (Macaca assamensis), Northern Pig-tailed macaque (Macaca lenina), Bengal Slow Loris (Nycticebus bengalensis), Indian Rhesus macaque (Macaca mulatta) and Capped Langur (Trachypithecus pileatus durga) [36]. The other main animals present are Indian elephant (Elephas maximus), sambar (Cervus unicolor), wild boar (Sus scrofa), jungle cats (Felis chaus), leopards (Panthera pardus), four types of squirrel, etc. The Sanctuary is harboured by other types of mammals, 232 species of birds and several types of snakes [34, 36].

\section{Socio-cultural diversity around gibbon wildlife sanctuary} Gibbon Wildlife Sanctuary exhibits a great ethnic cultural diversity surrounded mainly by human settlement and tea gardens. The major ethnic communities inhabited adjacent to wildlife sanctuary are Ahom, Chutiya, Koch-Rajbonshi, Kalita and tea tribes (Adivasi). Ahom, Chutiya and Koch-Rajbonshi people belong to Mongoloid groups. However, Kalita community of Assam commonly claimed themselves to belong to the Kshatriya caste and they considered as pure Aryans and it was thought that they were the first to introduce the Aryan culture in Assam [37, 38]. The tea tribes of Assam (Adivasi) are the people who were brought to the State in the British era as workers in tea gardens by colonial tea planters. The community consists of people belonging to the indigenous tribal community like Munda, Santhal. Bhumiz etc. Although all these communities are from different origin, nevertheless they are patriarchal by nature and belong to Assamese and use Assamese scripts [39].

The present study was conducted in the villages surrounding the Gibbon Wildlife Sanctuary and the information was collected mainly from the people of Ahom, Chutiya, Koch-Rajbongsi and Kalita communities.

\section{Data collection}

Field surveys were conducted in villages surrounding Gibbon Wildlife Sanctuary from March to August 2015. The ethnomedicinal data about the use of animals and their products were collected using the participatory rural appraisal (PRA) method, where the informants also sometimes become investigator themselves, involves an interview, informal meetings, open and group discussions and with semi-structured questionnaires [40-42].

During survey, details were asked in semi questionnaire form on the ethnozoological information, including local name of animal, part used, ailments, method of preparation, mode of administration, dosage, duration of treatment etc. concerning each of the traditional medicine [41-44]. The age of respondents varied from 30 to 80 years. A total of 62 individuals were interviewed. The respondents/informants were selected mainly on the basis of their experience, recognition as an expert knowledgeable persons, traditional healers concerning traditional medicine. Moreover, the detailed ingredients of medicine whether they use only animal parts or mixed with other ingredients like plant material were also noted. The scientific name and species name of animals were identified using relevant standard literature $[45,46]$ and also in association with Zoological Survey of India (ZSI), Shillong.

\section{Data analysis \\ Relative frequency of citation}

Relative frequency of citation (RFC) index shows the local importance of each species. The RFC value was calculated using the formula $\mathrm{RFC}=\mathrm{FC} / \mathrm{N}$; where $\mathrm{FC}$ is the number of informants mentioning about the use of the species and $\mathrm{N}$ is the number of informants participating in the survey [47]. This RFC index varies from 0 to 1 . When RFC index is 0 , it means that no one refers to the animal as useful and when RFC index is 1 , it indicates that all informants in the survey refer to the animal as useful [48].

\section{Fidelity level}

For the data analysis, fidelity level (FL) was calculated to determine the most commonly used animal species in the treatment of a particular disease category by the informants of the study area. Fidelity level is useful for identifying the resident's most preferred species in use for treating certain ailments. The FL was calculated [49] by using the formula as follows:

$$
\mathrm{FL}(\%)=N \mathrm{p} \times 100 / \mathrm{N}
$$

Where $N p$ is the number of informants that claim a use of a specific animal species to treat a particular ailment and $N$ is the total number of the informants who utilized the animals as a medicine to treat any given disease.

\section{Results and discussion \\ Demographic details of informants}

The inhabitants in villages surrounding the Sanctuary have a strong belief and knowledge regarding the source and use of traditional medicine. They use different plants, animals and animal byproducts for curing different ailments in their own indigenous ways. The knowledge regarding traditional medicine is usually confined to the local medicinal practitioners popularly known as Kabiraj, Bez and Bejini. Demographic information of the respondents was collected through face to face interaction. During the survey, respondents comprised an uneven distribution of the male-female ratio, where $69.4 \%$ respondents were male and only $30.6 \%$ were female. The 
high male-female ratio may indicate the dominancy of the participation of male medicinal practitioners over female medicinal practitioners. The same trend was also reported in other studies [30,31, 50]. The respondents belonged to mainly 4 ethnic groups i.e. Ahom, Chutiya, Koch-Rajbangsi and Kalita communities with the highest number of respondents from Ahom community (41.9\%) (Table 1).

The age of the respondents varied from 31 to 80 years. The percentage of local medicinal practitioner with age lower than fifty was found to be very less with only $21 \%$ as compared to $79 \%$ of the aged group of society above 50 years (Table 1 ). The demographic table of the respondents showed that the aged groups of the society were more knowledgeable about traditional medicinal uses than that of younger generation. This trend was very similar to the observation in other region of Assam made by Verma et al. [31] and may also indicate that the aged people were more experienced in the zootherapeutical practices which were passed to them by their elders. The reason of less traditional medicinal knowledge among the younger generation could be due to urbanization and assimilation of alien culture.

Table 1 Demographic profile of the informants included in survey $(N=62)$

\begin{tabular}{|c|c|c|}
\hline Demographic features & Number of people & Percentage (\%) \\
\hline \multicolumn{3}{|l|}{ Gender } \\
\hline Male & 43 & 69.4 \\
\hline Female & 19 & 30.6 \\
\hline \multicolumn{3}{|l|}{ Education } \\
\hline Primary education & 9 & 14.5 \\
\hline Secondary education & 36 & 58.1 \\
\hline Graduate & 17 & 27.4 \\
\hline Extra qualification & 0 & \\
\hline \multicolumn{3}{|l|}{ Religion } \\
\hline Hindu & 62 & 100 \\
\hline Muslim & 0 & \\
\hline Christian & 0 & \\
\hline \multicolumn{3}{|l|}{ Ethnicity } \\
\hline Ahom community & 26 & 41.9 \\
\hline Chutiya community & 11 & 17.7 \\
\hline Koch- Rajbangsi community & 9 & 14.5 \\
\hline Kalita community & 16 & 25.8 \\
\hline \multicolumn{3}{|l|}{ Age of traditional healer } \\
\hline Between 31 and 40 years & 4 & 6.5 \\
\hline Between 41 and 50 years & 9 & 14.5 \\
\hline Between 51 and 60 years & 20 & 32.3 \\
\hline Between 61 and 70 years & 26 & 41.9 \\
\hline Above 70 years & 3 & 4.8 \\
\hline
\end{tabular}

Most of the respondents had secondary level education while some of them were up to graduation level (Table 1 ). Only 12 respondents (19.4\%) were formally employed in government sector mainly as school teachers while others were mostly farmers, workers and local traditional healers. Most of the informants practiced this traditional therapy as a part time job to serve the society. However, some are renowned well known herbalist/healers who practice this traditional medicinal knowledge in large scale as their profession.

\section{Ethnozoological analysis}

The study recorded a total of 36 families, 44 genera, and 44 species of animals which were used to treat 40 different disease conditions. Table 2 summarizes the English name, scientific name, local name, the parts or byproduct of the species used to treat the disease(s) or ailment(s). These 44 animal species belonged to both verterates (25 species) and invertebrates (19 species). These animal species belong to 42 taxonomic groups among which insects occupied a highest number of animals (30.9\%), followed by mammals (23.8\%), fish (16.7\%), reptiles (11.9\%), amphibians (7.1\%), annelids (4.8\%) and gastropods (4.8\%) (Fig. 2). Insects may have been used mostly because of the easy availability in the study area, as was reported from Arunachal Pradesh, India [24]. The second highest zootherapeutic animals to be used are mammals as some of them are domesticated animals. However, in some reports mammals and reptiles are among the main group of animals used in folk medicine $[17,51,52]$. The use of mammals in traditional medicine has also been reported from other parts of India [30, 31, 53]. This finding demonstrates the importance of local faunal diversity in furnishing folk medicine as suggested by Alves and Rosa [16] who observed that faunal composition, accessibility and availability directly influence the type of zootherapeutic resources used in any given region.

The use of a number of animals and animal derived drugs by different ethnic communities to treat different diseases have also been reported from different geographical regions in India. A total of 15 different animal species were reported to be used for therapeutic purposes by the Mogya, Bawaria, and Meena community of Rajasthan [54]. About 26 animal species were reported to be used by the Naga tribe of Nagaland [26] and 48 different animals were recorded and documented to be used for different ethnomedicinal purposes among the Karbis of Assam [31]. Different indigenous tribal groups also sacrifice animals for different rituals and religious purposes in keeping with their mythological myths and beliefs. For example, people wear bear and tiger claws around their neck to protect from evils while animals 


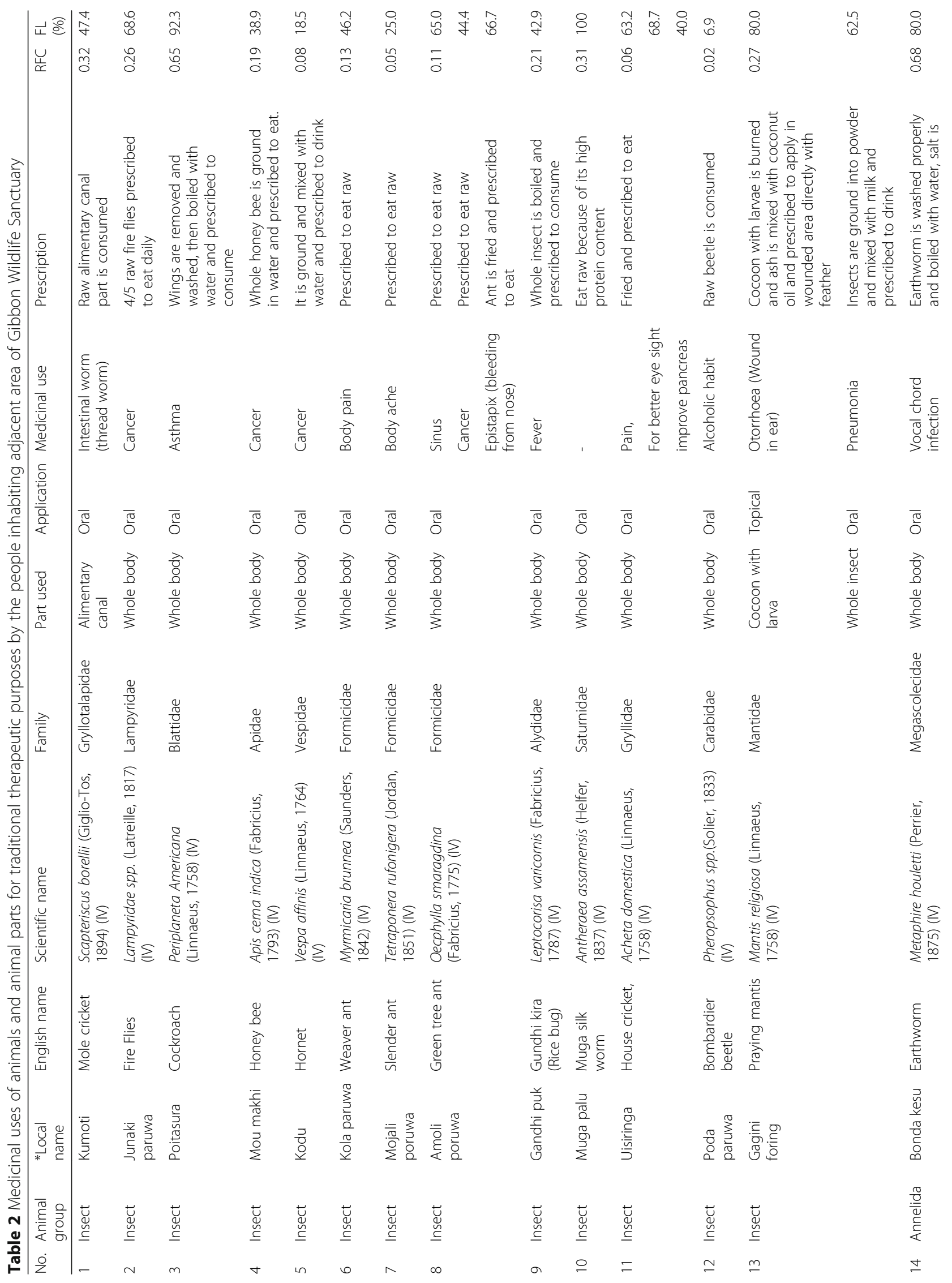




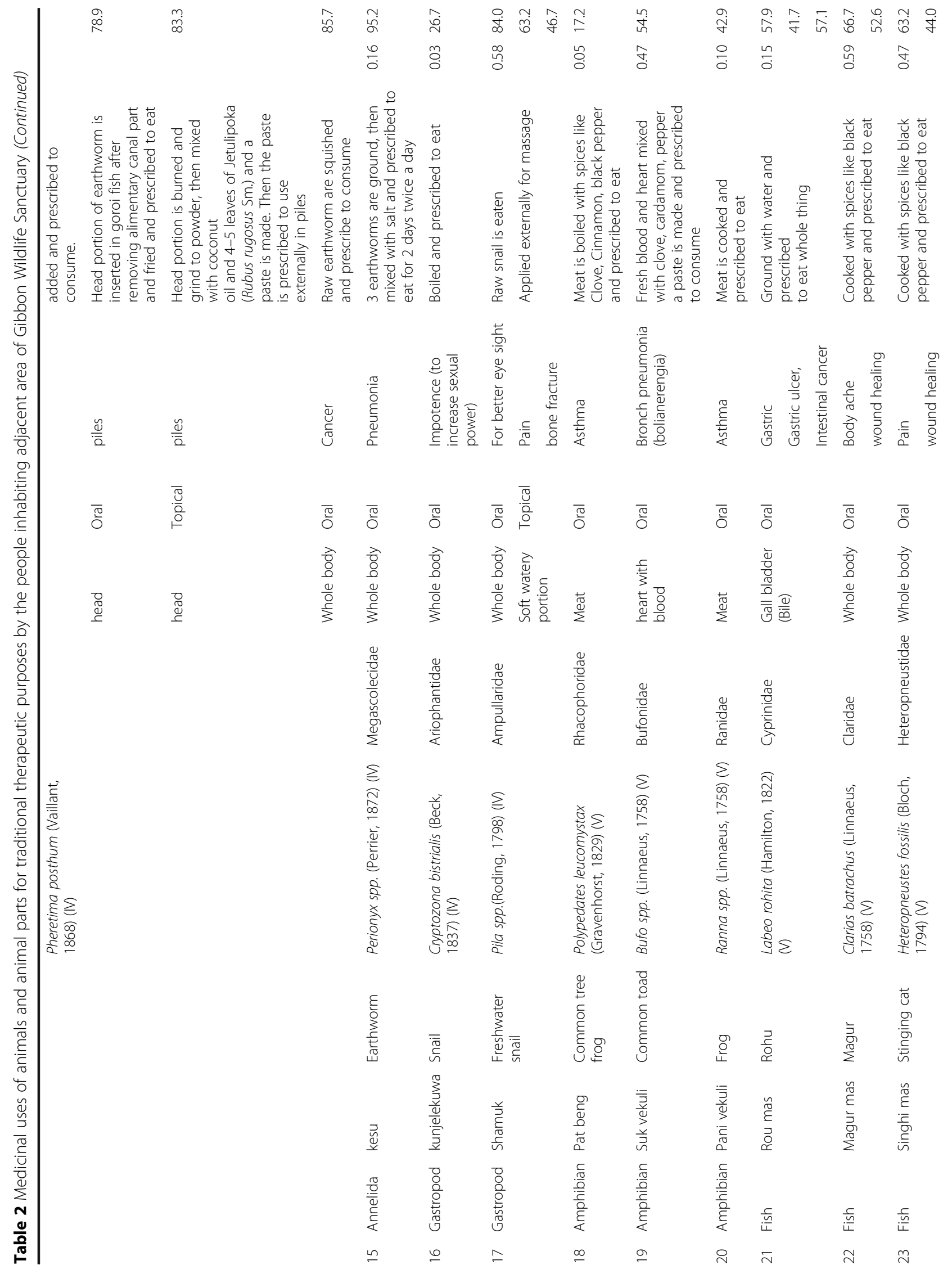




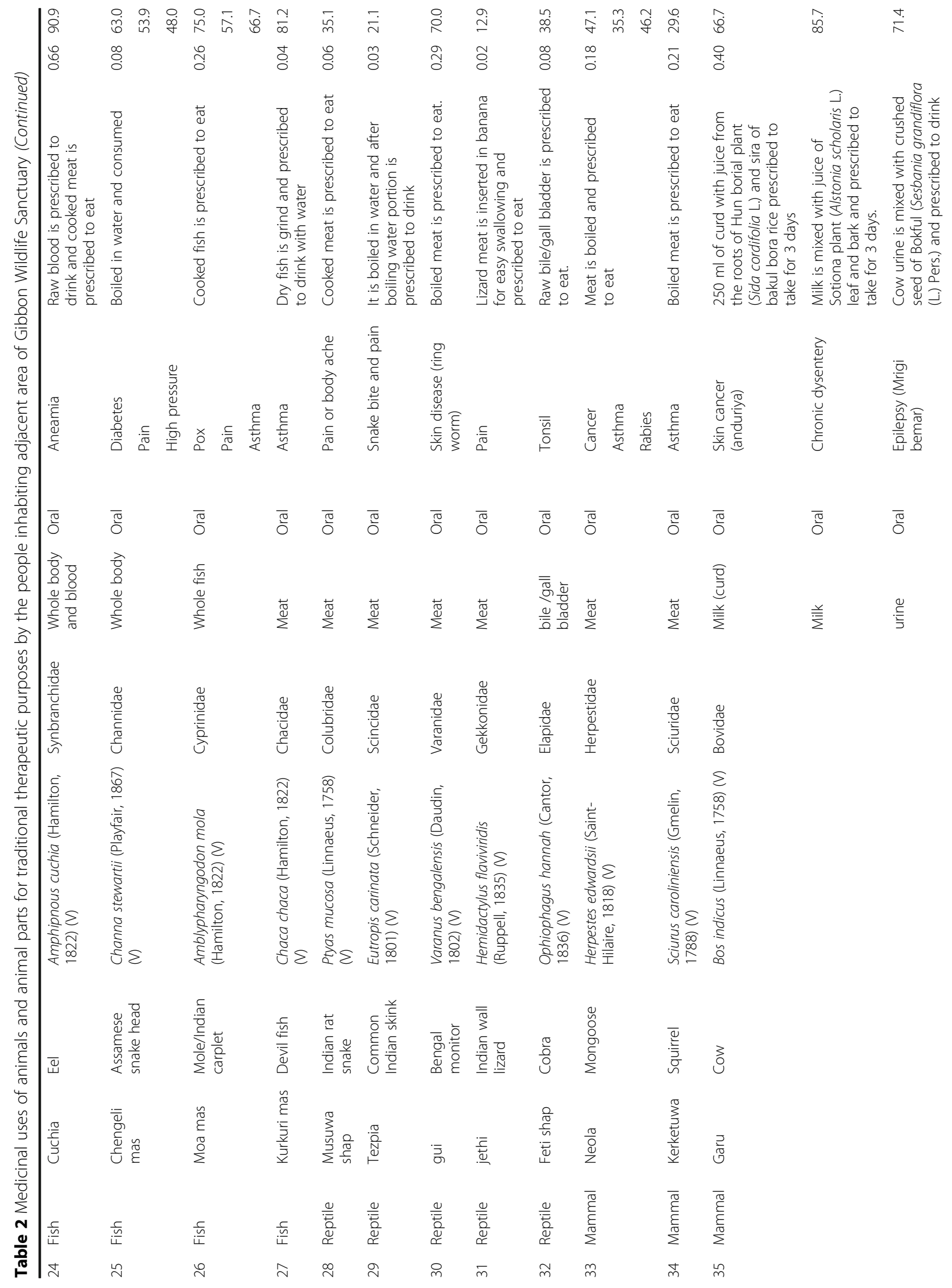




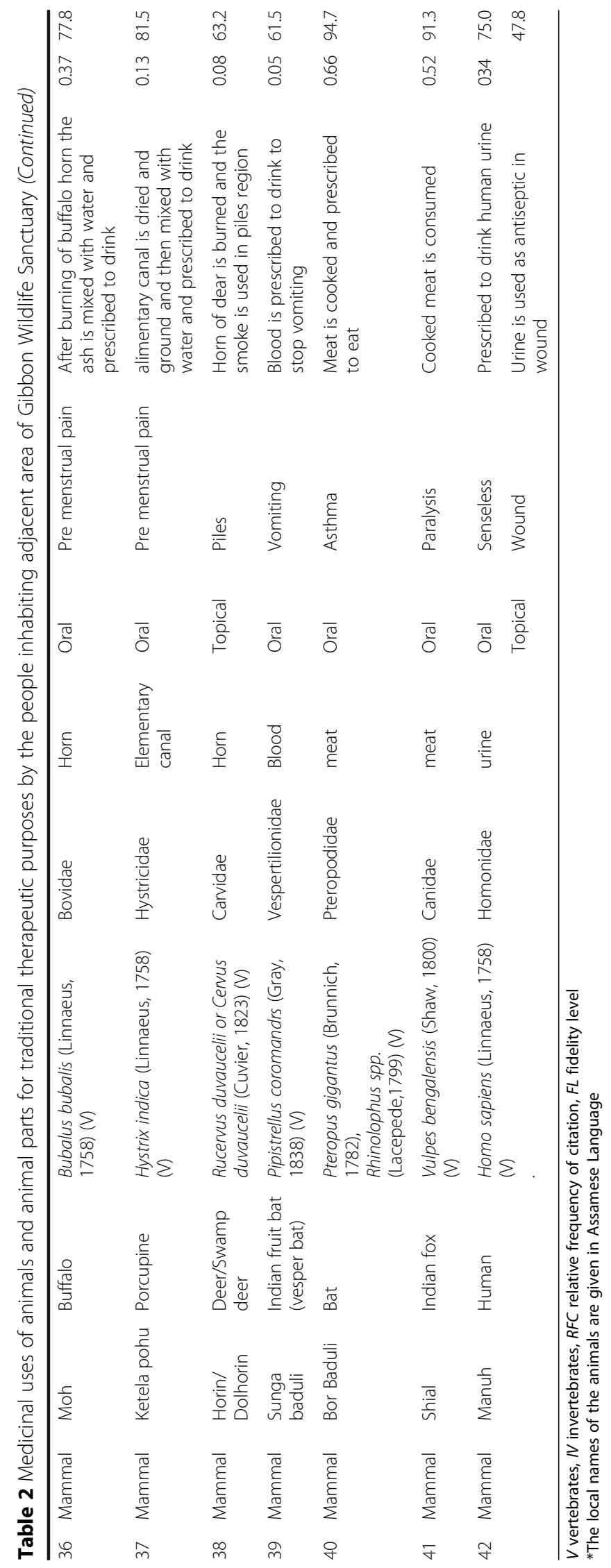




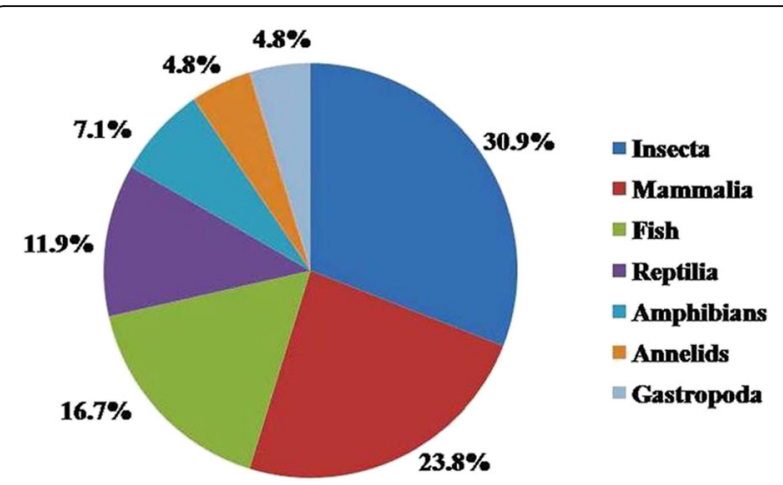

Fig. 2 Percentage of animal categories being used in zootherapeutic practices among the traditional healers in the adjoining areas of Gibbon Wildlife Sanctuary

like goat, buffalo, pigeon were sacrificed to please Gods for healing purposes [54-56].

From the study conducted, treatment was found for assisting 40 different ailments such as asthma, pneumonia, cancer, fever, piles, gastric, diabetes, snake bite, Pox, otorrhoes etc. (Table 2). The use of whole animals for medicinal purpose was recorded to be the highest (44.9\%), followed by other animals parts and byproducts like meat $(22.5 \%)$, blood, head, alimentary canal, gall bladder/bile, urine, horn, milk (each $4.1 \%$ ) and heart, cocoon with larva (each $2.0 \%$ ).

The result of our study depicted a total of 9 modes of preparation of animals for consumption against different ailments. The most commonly used way of taking animals in the study area is by consuming raw which occupied $28.7 \%$ of total preparation, followed by boiled, cooked and juice (each 16.3\%), paste (8.2\%), Ash (4.1\%), fried (6.1\%), decoction and smoke (each 2.0\%) (Fig. 3). Raw consumption of animals or animal parts in different therapeutic purposes is a common practice among different ethnic communities worldwide [2, 57]. Further, it was noted that the oral consumption of the preparations
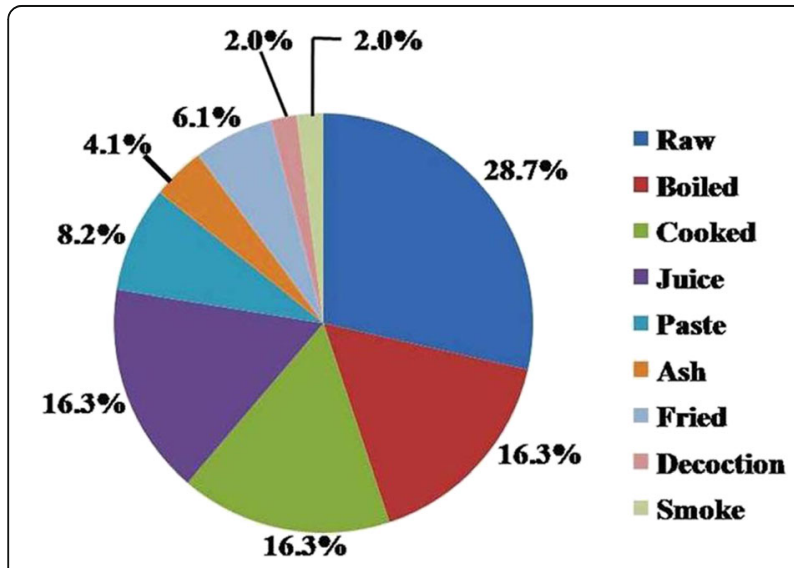

Fig. 3 Methods of preparation of different animals and animals parts (\%) to treat the ailments were much higher (88.1\%) than that applied topically (11.9\%) (Fig. 4). This is quite similar to the observation made in other studies [31, 57-59]. However, topical application is still a most important way of remedy to treat disease like pain, bone fracture, wound, piles, otorrhoea etc. [31, 57, 58].

The study also showed that for better therapeutic and remedial purposes plants and plant derived products were also used in combination with the animal parts and byproducts to treat some ailments (Table 2). For example, cow urine is mixed with crushed seed of Sesbania grandiflora (L.) Pers. (Bokful) for the treatment of epilepsy, cow milk is mixed with juice of Alstonia scholaris L. (Sotiona) leaves and bark to treat chronic dysentery etc. Some medicinal preparation where both plant and animals are utilized in combination is also reported from Brazil [7, 9, 60]. Some of the animal species being used by these ethnic groups, have also been reported to be used for similar purpose elsewhere. Cockroach (Periplaneta americana), found to treat asthma in our study site, has also been reported to have the same usage in Brazil [61]. Similarly Mishra and Panda [62] have documented the use of cockroach excreta in the treatment of bronchitis from coastal region of Orissa, India. Moreover, the present findings recorded the use of Hystrix indica elementary canal in the treatment of pre-menstrual pain, where as elementary canal of Hysrix indica was reported to be used as antiasthmatic in cough and cold among Pahari and Danawar tribe of central Nepal [63]. It was also noted that honey bees were used against treatment of cancer suspects and this observation could be in line with the findings of Jo et al. [64] where honey bee venom toxin and melittin were suggested for anticancer effect in ovarian cancer cells through induction of death receptor and inhibition of JAK2/STAT 3 pathway. Human urine was documented in the present study to be used against wound healing and recovery from senseless,

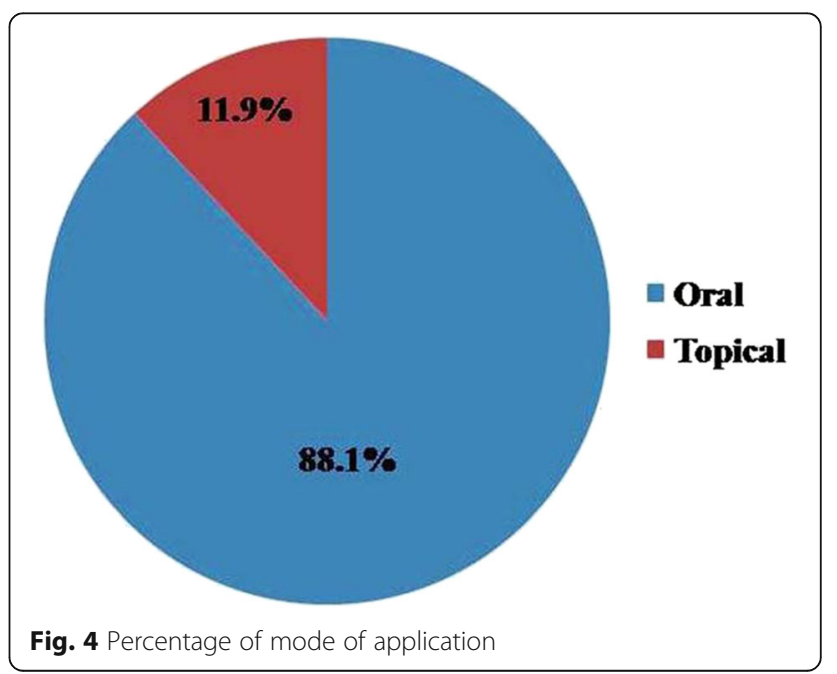


however, Verma et al. [31] have reported the use of human urine as a therapeutic against conjunctivitis and skin diseases by Karbi community of Assam, India. According to Zhang et al. [65], the medicinal usage of earthworms in China has a history of nearly 4000 years for the treatment of 80 different diseases like asthma, epilepsy, cancer etc. Present study also documents the use of earthworms against many diseases like vocal cord infection, piles, cancer, and pneumonia. Pharmacological importance of earthworms is also supported by the study of Dinesh et al. [66], where they showed the anticancer potential of peptides of coelomic fluid of earthworms. However, special precaution should be taken when animal tissue or parts from unknown sources are used as remedies due to possibility of transmission of severe and prevalent zoonoses and other side effects. Photographs captured during field survey showing the interaction with some traditional healers and some representative animals, animal parts and their storing method is given in Fig. 5.

\section{Quantitative analysis \\ Relative frequency of citation (RFC)}

Relative frequency of citation (RFC) index was calculated to determine the local importance of each species. The most cited animal species were: Metaphire houletti/ Pheretima posthum (RFC $=0.68)$, Pteropus gigantus $/$ Rhinolophus sp. $(\mathrm{RFC}=0.66)$, Amphipnous cuchia $(\mathrm{RFC}=0.66)$, Periplaneta Americana $(\mathrm{RFC}=0.65)$, Clarius batrachus $(\mathrm{RFC}=0.59)$, Pila spp. $(0.58)$, Vulpes bengalensis (0.52). The highest value of RFC index was scored by Metaphire houletti/Pheretima posthum which demonstrates the importance of this animal species in adjoining areas of Gibbon wildlife sanctuary, Assam, India as it was mentioned by a higher number of informants. However, animal species with low RFC values for instance Hemidactylus flaviviridis $(\mathrm{RFC}=0.02)$ and Pherosphus sp. $(\mathrm{RFC}=0.02)$ do not mean that they are not important locally but it may be that the most of the people are not aware of their therapeutic properties.

\section{Fidelity level (FL)}

Fidelity level is very helpful for identifying most frequently and preferably used species in the treatment of certain disease. This fidelity level varies from $1.0 \%$ to $100 \%$ on the basis of respondents claiming the use of certain animals for the same purpose. A higher FL of $100 \%$ or close to $100 \%$ for a specific animal indicates that all of the used reports mentioned the same method for using the animal for treatment for the same diseases [57]. The present study showed 5 animal species with a FL above 90\% (Table 2, Sl. No. 3,10,15, 24,41) such as Perplaneta americana which are used for the treatment of asthma (FL 92.3\%), Perionyx sp. used for treatment of pneumonia (F L 95.2\%), Amphipnous cuchia for treatment of anemia (FL 90.9\%), Vulpes bengalensis used for treatment of paralysis (FL 91.3\%) and Antheraea assamensis used as food for highly proteinacious contents with a FL $100 \%$. However Pherosophus sp. has the lowest fidelity level (FL 6.9\%). Observably, the remedies for frequently reported ailments have the maximum fidelity level and those with less number of reports have lowest FL values. From this study, the results indicate that in many cases same animal species were reported to be used for the healing of more than one ailment. This type of trends has also been found in different traditional medicinal remedies in different parts of the world [14, 23, 44, 67]. On the other hand, different animal species were sometimes used to treat the same disease. The use of different animals or remedies for the

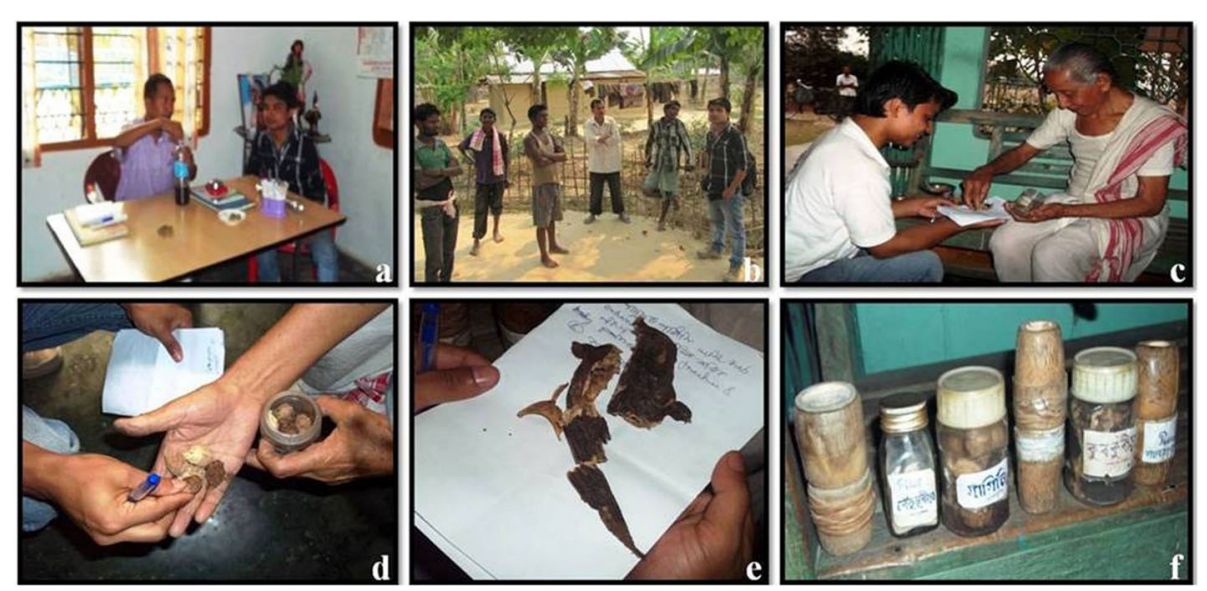

Fig. 5 Representative photographs during field survey showing traditional method of drug preparation by the local traditional healers with one of the authors (MPB). $\mathbf{a}, \mathbf{b}, \mathbf{c}$ Interaction and data collection from traditional healers. $\mathbf{d}$ Dry cocoon of Mantis religiosa; e Dry fish Chaca chaca; $\mathbf{f}$ Traditional stockes and jars of animals and animal parts 
same ailment is popularly valued as it provides an adaptation to the availability and accessibility of the possible animals [68].

In summary, this study indicates that traditional zootherapeutic practices play an important role in the primary health care system among the indigenous ethnic communities inhabiting near the Gibbon Wildlife Sanctuary, Assam, India. Due to lack of proper medical facilities and due to the strong belief on traditional medicine these people depend on various animal based medicines for different therapeutic purposes. It is necessary to take care of ecological balance and biodiversity conservation measure in terms of uses and sale of animals and animal byproducts for medicinal purpose. Many superstitions and myth may also be associated with traditional medicine, therefore, particular animal or its part, byproduct should be tested for their appropriate medicinal component. Further, due to death of elderly knowledgeable persons and rapid modernization, the traditional zootherapeutic knowledge is eroding and findings from present study should be helpful to preserve and document the knowledge of these ethnic groups on zootherapeutic usages for future.

\section{Conclusion}

Use of animals and animal derived products for indigenous medicinal purposes in the study site is the main primary health care system. This study is the first effort to document the traditional zootherapeutic knowledge common among the indigenous inhabitants surrounding Gibbon Wildlife Sanctuary. Traditional knowledge is not only significant for its pharmacological value, but also related with different cultural beliefs and sentiments of the indigenous people. This study provides the base for further scientific validation of the therapeutic efficacy of various zootherapeutic tradiotional uses by these people and finding novel biological compound(s) towards discovery of new drugs. This may also help in better understanding of traditional zootherapeutic medicine, its interrelationship with the socioeconomic and ecological values of the region, biodiversity conservation and management strategies of animal resources for sustainable use.

\section{Acknowledgements}

We are grateful to all the respondents (traditional healers) of the surrounding areas of Gibbon Wildlife Sanctuary for sharing their valuable traditional knowledge and the forest officials for their support and help during the field survey.

\section{Funding}

Not applicable.

\section{Availability of data and materials}

All the data generated or analysed during this study are included in this article (Tables 1 and 2).

\section{Authors' contributions}

The significance of this first ethnozoological study in this specified region and components of the work including questionnaire etc. were conceptualized by SBP. Necessary ethnozoological field surveys by collecting data through personal interaction/interviews/semi-structured questionnaire in the adjoining areas of Gibbon wildlife sanctuary of Assam were done by MPB. Preparation of graphs, tables, statistical analysis and initial manuscript preparation were done by MPB. Compilation of data, analysis and interpretation of data was done jointly by both the authors. Further corrections, scrutiny and critical appraisal of the manuscript was done by SBP. We take the responsibility for the integrity of the work presented in this manuscript. Both the authors have read and approved the final manuscript.

\section{Ethics approval and consent to participate}

The detail of the work plan of present ethnozoological study was approved by the Institutional Ethical Committee, North-Eastern Hill University Shillong, Meghalaya, India. Participants were given an explanation of the aims, methodology and outcome of the study and the consent was obtained verbally before the interview was conducted.

\section{Consent for publication}

Consent to publication of any picture, included in the paper has been obtained from the study participants.

\section{Competing interests}

The authors declare that they have no competing interests.

\section{Publisher's Note}

Springer Nature remains neutral with regard to jurisdictional claims in published maps and institutional affiliations.

Received: 16 March 2017 Accepted: 18 June 2017

Published online: 30 June 2017

\section{References}

1. Alves RRN, Rosa IL. Why study the use of animal products in traditional medicine? J Ethnobiol Ethnomed. 2005;1:1-5.

2. Vijaykumar S, Yabesh JEM, Prabhu S, Ayyanar M, Damodaran R. Ethnozoological study of animals used by traditional healers in the silent vally of Kerala. India J Ethnopharmacol. 2015;162:296-305.

3. World Health Organization. Guideline on the conservation of medicinal plants. Geneva: 1993. p. 1-38.

4. World Health Organization. Traditional medicine strategy 2014-23. 2014. p. $1-76$.

5. Crag GM, Newman DJ. Natural products: a continuing source of novel drugs leads. Biochemica et Biophysica Acta. 2013;180:3670-95.

6. Costa-Neto EM. Animal-based medicines: biological prospection and the sustainable use of zootherapeutic resources. Annals Acad Bras Cienc. 2005; 77:33-43.

7. Costa-Neto EM. Healing with animals in Feira de Santana city. Bahia Brazil J Ethnopharmacol. 1999:65:225-30.

8. Alves RRN, Alves HN. The faunal drugstore: animal-based remedies used in traditional medicines in Latin America. J Ethnobiol Ethnomed. 2011;7:1-43.

9. Alves RRN, Rosa IL, Santana GG. The role of animal-derived remedies as complementary medicine in Brazil. Bio Sci. 2007;57(11):949-55.

10. Costa-Neto EM. Implications and applications of folk zootherapy in the state of Bahia. Northeastern Brazil Sustain Dev. 2004;12(3):161-74.

11. Alves RRN, Barbosa JAA, Santos SLDX, Souto WMS, Barboza RRD. Animal based remedies as complementary medicines in the semi-arid region of northeastern Brazil. Evid Based Complement Alternat Med. 2011;2009:1-15.

12. Martinez GJ. Use of fauna in the traditional medicine of native Toba (qom) from the argentine gran Chaco region: an ethnozoological and conservationist approach. Ethnobio Conserv. 2013;2:1-43.

13. China National Corporation of Traditional and Herbal medicine. Materia medica commonly used in China Beijing. China Beijing: Science Press; 1995.

14. Alves RRN, Souto WMS, Barboza RRD, Bezerra DMM. Primates in traditional folk medicine: a world overview. Mammal Rev. 2010;40:155-80.

15. Lev E, Amar Z. Ethnopharmacological survey of traditional drugs sold in Israel at the end of the 20 th century. J Ethnopharmacol. 2000;72:191-205.

16. Alves RRN, Rosa IL. Zootherapeutic practices among fishing communities in North and Northeast Brazil: a comparison. J Ethnopharmacol. 2007;111:82-103.

17. Alves RRN, Vieira WLDS, Santana GG. Reptiles used in traditional folk medicine: conservation implications. Biodivers Conserv. 2008;17:2037-49. 
18. Alfred JRB. Faunal diversity in India: an overview Faunal Diversity in India, vol. I-VIII; 1998. p. 1-495.

19. Puri SK. Biodiversity Profile of India (Text Only). 2007. http://ces.iisc.ernet.in/ hpg/cesmg/indiabio.html. Retrieved 20 June 2007.

20. Unnikrishnan PM. Animals in Ayurveda. J Amruth. 1998:1-15.

21. Mahawar MM, Jaroli DP. Traditional zootherapeutic studies in India: a review. J Ethnobiol Ethnomed. 2008:4:17-29.

22. Alonso-Castro AJ. Carranza-Alvarez C, Maldonodo-Miranda JJ, JacoboSalcedo MDR, Quezada-Rivera, Lorenzo-Marquez H, Figueroa-Zuniga LA, Fernandez-Galicia C, Rios-Reyes NA, de Leon-Rubio MA, Rodriguez-Gallegos V, Medellin-Milan P. Zootherapeutic in Aquismon, San luis Potosis, Mexico. J Ethnopharmacol. 2011;138:233-7.

23. Teron R, Borthakur SK. Biological motifs and designs on traditional costumes among Karbis of Assam. Indian J Trad Knowl. 2012;2:305-8.

24. Chakravorty J, Ghosh S, Meyer-Rochow VB. Practices of entomophagy and entomotherapy by members of the Nyshi and Galo tribes, two ethanic groups of the state of Arunachal Pradesh (North-East India). J Ethnobiol Ethnomed. 2011a;7:5-18.

25. Chakravorty J, Meyer-Rochow VB, Ghosh S. Vertebrate used for medicinal purposes by members of the Nyishi and Galo tribes in Arunachal Pradesh (North-East India). J Ethnobiol Ethnomed. 2011b;7:13-26.

26. Jamir NS, Lal P. Ethanozoological practice among Naga tribes. Indian J Trad Knowl. 2005;1:100-4

27. Turnia I, Prasad SB. Traditional zootherapeutic practices by the indigenous Khasi natives of Sohiong village, East Khasi hill district, Meghalaya. India Asian J Complement Altern Med. 2017;2017(1):1-8.

28. Sajem AL, Gossai K. Traditional use of plants by the Jaintia tribes in North Cachar Hills district of Assam, northeast India. J Ethnobiol Ethnomed. 2006;2:1-7.

29. Betlu ALS. Indigenous knowledge of zootherapeutic use among the Biate tribe of Dima Hasao District, Assam. Northeastern India J Ethnobiol Ethnomed. 2013;9:56-70.

30. Borah MP, Prasad SB. Ethnozoological remedial uses by the indigenous inhabitants in adjoining areas of Pobitora wildlife sanctuary, Assam. India. Int J Pharm Pharm Sci. 2016;8(4):90-6.

31. Verma AK, Prasad SB, Rongpi T, Arjun J. Traditional healing with animals (zootherapy) by the major ethnic group of Karbi Anglong district of Assam. India Int J Pharm Pharm Sci. 2014;6:1-8.

32. Trivedi PC. Ethnobotany: an overview. In Ethnobotany edited by: Trivedi PC. Jaipur: Aavishkar publisher; 2002.

33. Chetri D, Chetri R. Hoolock gibbon conservation in India. Gibbon J. 2011;6:7-12

34. Devi OS, Saikia PK. A checklist of avian fauna of gibbon wildlife sanctuary, Jorhat District. Assam NeBIO. 2010;1(3):1-7.

35. Sarmah R, Saikia A. Folklore medicine practiced by traditional healers of fringe village of gibbon wildlife sanctuary, Assam. India Acta Biomedica Scientia. 2016;3(4):227-33.

36. Gogoi P. Gibbon wild life sanctuary: a prospect for eco-tourism. Int J Sci Eng Res. 2013;4(10):549-59.

37. Baruah L. Cultural assimilation among Ahom, Chutiys, Kachari, Mishing, Rabha and Deoris ethnic communities of Assam. BEST: IJHAMS. 2014; 2(7):59-64.

38. Ray NR. Koch Rajbonshi and Kamata puri. Centre for Koch Rajbonshi Studies and Development (CKRSD), Guwahati. 2013.

39. Sengupta S. The Tea Labourers of North-East India: An Anthropo-historical perspective. Mittal publication, New delhi (India). 2009; p.1-295.

40. Kim H, Song MJ. Analysis and recordings of orally transmitted knowledge about medicinal plants in the southern mountainous region of Korea. J Ethnopharmacol. 2011;134:676-96.

41. Huntington HP. Using traditional ecological knowledge in science: methods and applications. Ecol Appl. 2000;10:1270-4.

42. Alexiades MN. Selected guidelines for ethnobotanical research: a field manual. In: advances in economic botany. Volume 10. The New York Botanical Garden: Bronx; 1996.

43. Morvin Yabesh JE, Prabhu S, Vijaykumar S. An ethnobotanical study of medicinal plants used by traditional healers in Silent Valley of Kerala. India. J Ethnopharmacol. 2014;154:774-89.

44. Jain SK. Dictionary of Indian folk medicine and Ethnobotany. New Delhi: Deep Publisher; 1991.

45. Ali S. The book of Indian birds. Bombay. Natural History Society: Bombay; 1996.
46. Prater $\mathrm{SH}$. The book of Indian animals. Bombay Natural History Society. 1996:

47. Vitalini S, Iriti M, Puricelli C, Ciuchi D, Segale A, Fico G. Traditional knowledge on medicinal and food plants used in Val san Giacomo (Sondrio, Italy)- an alpine ethnobotanical study. J Ethnopharmacol. 2012;145:517-29.

48. Mootsamy A, Mahomoodly MF. A quantitative ethnozoological assessment of traditionally used animal based therapies in the tropical island of Mauritius. J Ethnopharmacol. 2014;154(3):847-57.

49. Friedmen J, Yaniv Z, Dafni A, Palewitch D. A preliminary classification of the healing potential of medicinal plants, based on a rational analysis of an ethnopharmocological field survey among Bedouins in the Negev desert. Israel J Ethnopharmacol. 1986;16:275-87.

50. Mahawar MM, Jaroli DP. Traditional knowledge on zootherapeutic uses by the Saharia tribe of Rajasthan. India. J Ethnobiol Ethnomed. 2007;3:25-30.

51. Alves RRN, Feijo A, Barboza RRD, Souto WMS, Fernandes-Ferreira $\mathrm{H}_{\text {, }}$ Cordeiro-Estrela P, Langguth A. Game mammals of the Caatinga biome. Ethnobio Conserv. 2016;5:1-51.

52. Fernandes-Ferreira H, Mendonca SV, Cruz RL, Borges-Nojosa DM, Alves RRN. Hunting of herpetofauna in montane coastal and dryland areas of northeastern Brazil. Herpetol Conserv Bio. 2013;8:652-66.

53. Kakati LN, Doulo V. Indigenous knowledge system of zootherapeutic use by Chakhesang tribe of Nagaland. India J Human Ecol. 2002;13(6):419-23.

54. Mahawar MM, Jaroli DP. Animals and their products utilized as medicine by the inhabitants surrounding the Ranthambhore National Park. India. J Ethnobiol Ethnomed. 2006;2:46-51.

55. Solanki GS, Chutia P. Ethno-zoological and socio-cultural aspects of Monpas of Arunachal Pradesh. J Human Ecol. 2004;4:251-4.

56. Alves RRN. Fauna used in popular medicine in Northeast Brazil. J Ethnobiol Ethnomed. 2009:5:1-11.

57. Kim H, Song MJ. Ethnozoological study of medicinal animals on Jeju island. Korea J Ethnopharmacol. 2013;146:75-82.

58. Jaroli DP, Mahawar MM, Vyas N. An ethanozoological study in the adjoining areas of Mount Abu wildlife sanctuary. India J Ethnobiol Ethnomed. 2010;6:6-13.

59. Benitez G. Animal used for medicinal and magico-religious purposes in western Granada Province. Andalusia J Ethnopharmacol. 2011:137:1113-23.

60. Alves RRN, Filho GAP. Commercialization and use of snakes in North and northeastern Brazil: implications for conservation and management. Biodivers Conserv. 2007;16:969-85.

61. Costa-Neto E, Oliveira MVM. Cockroach is good for asthma: zootherapeutic practices in northeastern Brazil. HER. 2000;7:41-51.

62. Mishra N, Panda T. Zootherapeutical uses of animal diversity in coastal district of Orissa. India Br J Pharmacol Toxicol. 2011:2:154-8.

63. Lohani U. Zootherapeutic knowledge of two ethnic populations from Central Nepal. EthnoMed. 2012;6:45-53.

64. Jo M, Park MH, Kollipara PS, An BJ, Song HS, Han SB, Kim JH, Song MJ, Hong JT. Anticancer effect of bee venom toxin and melittin in ovarian cancer cell through induction of death receptor and inhibition of JAK2/STAT3 pathway. Toxicol Appl Pharmacol. 2012;258:72-81.

65. Zhang FX, Guo B, Wang HY. The spermaticidal effects of earthworm extract and its effective constituents. Soil Biol Biochem. 1992;24:1247-51.

66. Dinesh MS, Sridhar S, Chandana PG, Pai V, Geetha KS, Hegdge N. Anticancer potentials of peptides of coelomic fluid of earthworm Eudrilus eugeniae. Biosci Biotechnol Res Asia. 2013;10:601-6.

67. Ferreira FS, Brito S, Ribeiro S, Almedia W, Alves RRN. Zootherapeutics utilized by residents of the community Poco Dantas, Crato-CE. Brazil J Ethnobiol Ethnomed. 2009;5:21-31.

68. Alves RRN, Rosa IL. From cnidrians to mammals: the use of animals as remedies in fishing communities in NE Brazil. J Ethnopharmacol. 2006; 107(2):259-76 